$$
\text { キャビティ面圧分布計測への触覚センサの応用 }
$$

\author{
村田泰彦*1 ・ 横井秀俊*1 ・河 崎浩 志*2
}

\title{
Application of Tactile Sensor to the Measurement of Melt Pressure Distributions along Cavity Surface
}

\author{
Yasuhiko Murata*1, Hidetoshi YokoI*1, Hiroshi Kawasaki*2
}

In order to clarify undesirable phenomena in an injection molding such as residual stress or sink mark, it is very important to measure the melt pressure distribution in the injection mold cavity.

In this paper, we have proposed a new method for measuring the melt pressure distribution by using a mold with a pressure transmission pin array and a tactile sensor. The results obtained through the new measurement method are summarized below.

(1) After experimentally examining the output of the tactile sensor. We confirmed that the deflection of each sensing point is not more than $6 \%$, and it is necessary to keep the temperature around the sensor under $35^{\circ} \mathrm{C}$ to increase the pressure measurement range.

(2) We proposed an effective calibration method using a quartz pressure sensor during the injection molding process.

(3) Based on the above measurement method, we measured the pressure distribution of low density polyethylene under various holding pressure period conditions, and the results detailed proved that this method is effective. For example, when the holding pressure period is longer than the gate sealing period, the decrease in the pressure starts around the end of the cavity. Conversely, when the holding pressure period is shorter than the gate sealing period, the decrease in the pressure starts around the gate.

Key words : Injection molding/Injection mold/Measurement/Pressure distribution/ Tactile sensor

\section{1. 緒言}

射出成形に扮ける型内樹脂圧力計測は, 樹脂流動挙

*1 東京大学生産技術研究所 第 2 部

東京都港区六本木 7-22-1 ( $\mathbf{T}$ 106)

Institute of Industrial Science, University of Tokyo

7-22-1 Roppongi, Minato-ku, Tokyo 106 Japan

*2 凸版印刷(株) パッケージ事業本部 TPC 事業部

包装研究所

埼玉県北葛飾郡杉戸町高野台南 4-2-3

Toppan Printing Co., Ltd.

4-2-3 Takanodai-Minami, Sugito-machi,

Kitakatsushika-gun, Saitama 345 Japan

1995. 9.26 受理
動・温度計測技術と比較して汎用技術としての確立が 早い，現在，沉用のひずみダージ式1),2)から，水晶圧 電式圧力センサ3)のように $200 \mathrm{MPa}$ までの高い圧力 を計測できるものまでが，成形過程モニタ一用および 研究開発用として広く実用化されている。 また，最近 では超音波を利用した圧力計測法の研究も進められて いる4)、しかし，これらはすべて，ランナー・キャビ ティ内 2,3 か所俉置して行らスポッ卜計測法にと どまっている.

現在, 低圧射出成形法, ガスアシスト射出成形法な ぞのキャビティ内に抢ける樹脂圧力分布を能動的に制 


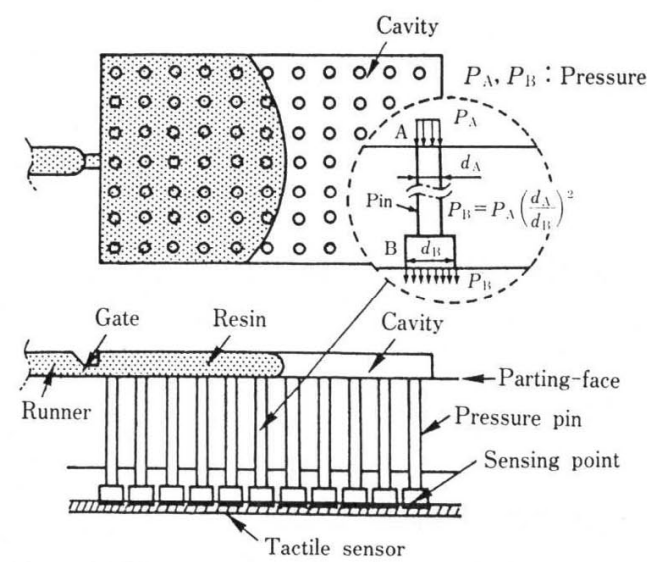

Fig. 1 Measuring method for melt pressure distribution along cavity surface

御することで成形品の品質向上を目指す新成形法が出 現し,また, 残留応力, およびひけ, そりなどの数值 シミュレーターの開発が盛んに行われている，そのた め, 樹脂圧力を点ではなく, キャビティ全域に淤ける 面分布として詳細に計測することの必要性がますすす 高まりつつある。

上記計測法がスポット計測にとどまっている原因は， （1）センサの計測部寸法が大きいために，これらをキ ヤビティ面に細かく配列できないこと，(2)アンプを 含めたセット当たりの価格が高いことにあると言える. このよらな現状から, 著者の一部らは, 既報らに沶い て樹脂圧力分布を詳細に計測するためのすりガラスを 用いた面圧分布可視化法を提案した. しかし, 同手法 では画像処理などのデータ解析に多くの時間を必要と し，簡便法とは言えなかった。

本論文では, 簡易的に压力分布を計測するために, 圧力伝達ピンアレイと压力分布計測用触覚センサから 構成される新しいキャビティ面圧分布計測法を提案し た、そして, 実成形条件下での計測実験を通して, 本 手法の有効性の確認を行った. 以下に, その概要につ いて報告する.

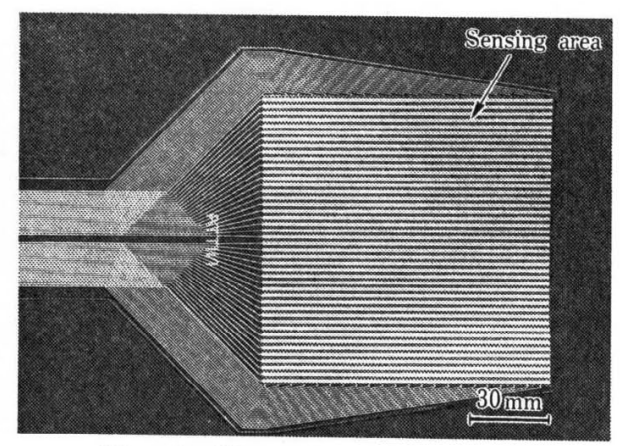

Fig. 2 View of tactile sensor

\section{2. 面圧分布計測原理および金型基本構造}

\section{1 計 測 原 理}

Fig. 1 はキャビティ面圧分布の計測原理を示してい る. 多数の圧力伝達ピンが, キャビティ壁面に対して 面一になるように等間隔に配列されている. 圧力伝達 ピンの底部 B には, 多数の感圧部が格子状に配列され たシート状の圧力分布計測用触覚センサが設置されて いる、樹脂のフローフロントがピン上部を通過すると, それぞれのピンを介して樹脂圧力が触覚センサに伝達 され, 分布として検出される。

\section{2 触覚センサ}

本論文で使用した触覚センサは, Fig. 2 に示すニッ タ製のタクタイルセンサI-SCAN 100 (以後本センサ と呼称する) である.

本センサは, 圧力負荷による変形量に比例して電気 抵抗值が変化する導電性物質を, 行電極と列電極の交 点に挟み込み, 各交点が圧力検出点となるように格子 状に配置されたものである.本センサ出力は, パーソナ ルコンピューター（日本電気製 PC-9801 RX) に記録 され,グラフィック処理される. Table 1 に本センサ の仕様を示す. $44 \times 44$ 点 (縦×横) の感圧部が 2.54 $\mathrm{mm}$ 間隔に配されている.

本センサの圧力測定範囲は $0.8 \sim 7.0 \mathrm{MPa}$ で, 通常 成形時のキ+ビティ内樹脂圧力に比べて数倍低い。そ こで本論文では, Fig. 1 に示すよらにピンを段付き形 状とし, ピン $\mathrm{A}$ 部に作用する圧力を面積比 $\left(d_{\mathrm{A}} / d_{\mathrm{B}}\right)^{2}$ 倍だけ分散させて B 部に伝達するような工夫を施した。 これにより, 後述する压力伝達ピン寸法から計算する と, 本計測金型では, 理論上 Table 1 の測定範囲の 6.25 倍までの樹脂圧力計測が可能となる.

\section{3 金型基本構造}

Fig. 3 は計測金型固定側の基本構造を示している. 本金型は, 圧力伝達ピンアレイブロックの設置された 上プレートとセンサが固定された下プレートとから構

\section{Table 1 Specifications of tactile sensor}

\begin{tabular}{l|c}
\hline Material of sensor film & Polyester \\
\hline Sensor dimensions $(L \times W \times T)$ & $112 \times 112 \times 0.1$ \\
\hline Number of sensing points & $44 \times 44$ \\
\hline $\begin{array}{r}\text { Pitch of each sensing points } \\
(\mathrm{mm})\end{array}$ & 2.54 \\
\hline $\begin{array}{r}\text { Pressure measuring range } \\
(\mathrm{MPa})\end{array}$ & $0.8-7.0$ \\
\hline Sampling rate $\quad(\mathrm{Hz})$ & 50 \\
\hline
\end{tabular}




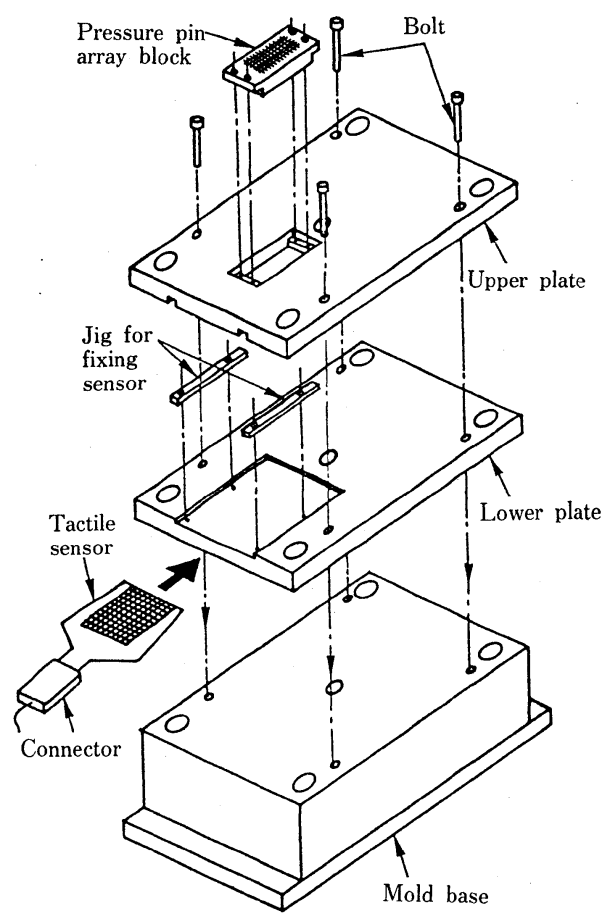

Fig. 3 Schematic structure of the measurement mold (Stationary side)

成される面圧分布計測プレートが，固定側モールドべ 一スに取り付けられた構造となっている．上下プレー トにはそれぞれ温調配管が設けられており，プレート 温度の制御が可能となっている.

Fig. 4 にキャビティ形状を示す. 厚さ $2 \mathrm{~mm}$ の矩形 キャビティ内に $25 \times 9$ 本, 合計 225 本の圧力伝達ピ ンが本センサ感圧部ピッチと同じ間隔で綎横に配され ている. 圧力伝達ピンの直径は, $d_{\mathrm{A}}=\phi 1.0 \mathrm{~mm}, d_{\mathrm{B}}=$ $\phi 2.5 \mathrm{~mm}$ (Fig. 1 参照) である. 本実験では, C点 の圧力伝達ピソと対向するキャビティ壁面側のエジェ クタピン下に水晶圧電式圧力センサ（日本キスラー製 Type 9221）を挿入し， 圧力の同時計測を行った。 た，センサ周辺温度を計測するために，センサ直下の 下プレートには銅ーコンスタンタン 熱電対（林電工製 シートカップル）が貼付されている。

\section{3. 実験方法}

\section{1 センサ出力特性評価実験}

実成形条件下での計測実験任先立ち，本センサをキ ヤビティ面圧分布計測に適用する場合に，事前に把握 して抢かなければならない基本特性の検討を行った。

本論文では，(1）金型温度設定変更などによるセ ソサ周辺温度変化がセンサ出力に及ぼす影響, (2)均

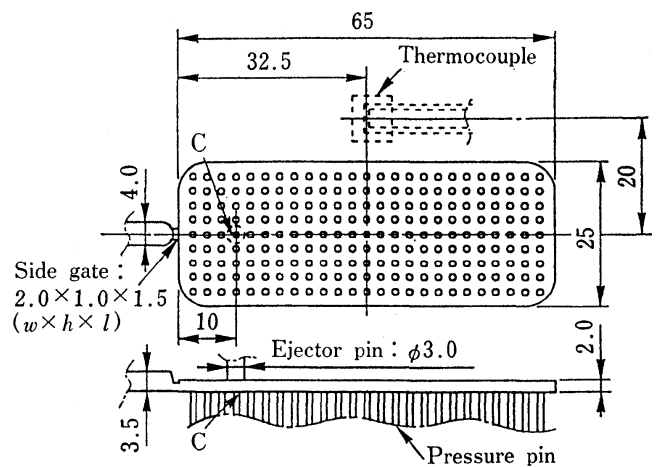

Fig. 4 Cavity shape and pressure-pins arrangement pattern (Units : $\mathrm{mm}$ )

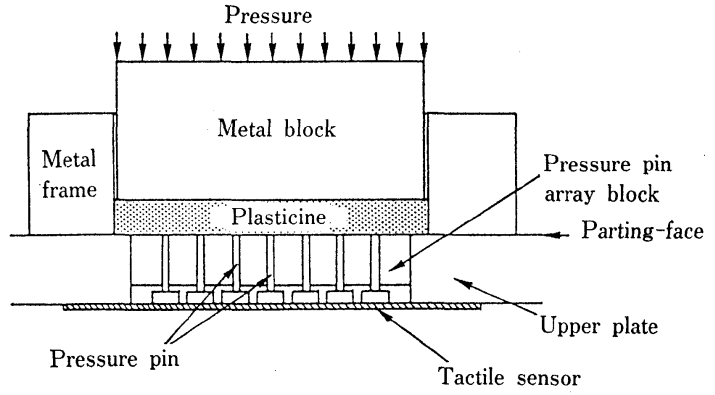

Fig. 5 Experimental apparatus for examining the output of tactile sensor

等圧力負荷時に㧊ける 225 点の各感圧部間の出力誤差 (ばらつき)，(3)繰り返し負荷-除荷条件下に抢けるセ ンサ出力の再現性, 以上 3 項目について検討を行った.

Fig. 5 は，上記 $(1)$ (2)の検討のだめ製作した出 力評価装置を示している. 本計測金型固定側のパーテ ヘング面上に金属製の四角形のフレームを取り付け, フレームの内側にプラスチシンを充填し，金属ブロッ クを介してその上から万能試験機（島津製作所製オー トグラフ AG-10 TE) にて加圧する。これにより,225 本のピンに所定の均等圧を加觉ることが可能となる. な特，センサ周辺温度は，下プレートに貼付された銅一 コンスタンタン熱電対 (Fig. 4 参照) 出力を基準とし $\tau$, 金型温調器 (松井製作所製 MC3-135/31 HX) 飞 より制御した。 また，（3）の評価は，感圧部 1 点のみ に負荷することのできる重錘式加圧治具(負荷圧力5.8 $\mathrm{MPa}$ ）を用いて，一定温度条件下で行った.

\section{2 キャビティ面圧分布計測実験}

Table 2 は型内樹脂圧力分布計測実験の成形条件を 示している，実験に使用した樹脂は，低密度ポリエチ レン (LDPE, 三井石油化学工業製 ミランン 68), 特 よびポリプロピレン ( PP, 三井石油化学工業製 ハイ ポール J 700), 汎用ポリスチレン (GPPS, 住友化 
Table 2 Molding conditions

\begin{tabular}{l|c|c|c}
\hline \multicolumn{1}{c|}{ Resin } & LDPE & PP & GPPS \\
\hline Injection rate $\left(\mathrm{cm}^{3} / \mathrm{s}\right)$ & \multicolumn{3}{|c}{9.3} \\
\hline $\begin{array}{r}\text { Resin temperature } \\
\left({ }^{\circ} \mathrm{C}\right)\end{array}$ & \multicolumn{2}{|c|}{180} & 210 \\
\hline $\begin{array}{r}\text { Mold temperature } \\
\left({ }^{\circ} \mathrm{C}\right)\end{array}$ & \multicolumn{2}{|c|}{23} & 22 \\
\hline $\begin{array}{r}\text { Holding pressure } \\
(\mathrm{MPa})\end{array}$ & \multicolumn{3}{|c}{28.8} \\
\hline $\begin{array}{l}\text { Holding pressure } \\
\text { period }\end{array}$ & $5.0,9.0$ & 7.0 & 8.0 \\
\hline
\end{tabular}

学工業製エスブライト $2 \mathrm{~V}$ ) である. 本実験では，保 圧時間を変化させて計測を行った。使用射出成形機は, 東洋機械金属製の Ti-80 G (型締力 80 トン) である.

\section{4. 実験結果および考察}

\section{1 センサ出力特性評価}

\section{a . センサ周辺温度の影響}

Fig. 6 は負荷圧力と本センサ出力の関係を示してい

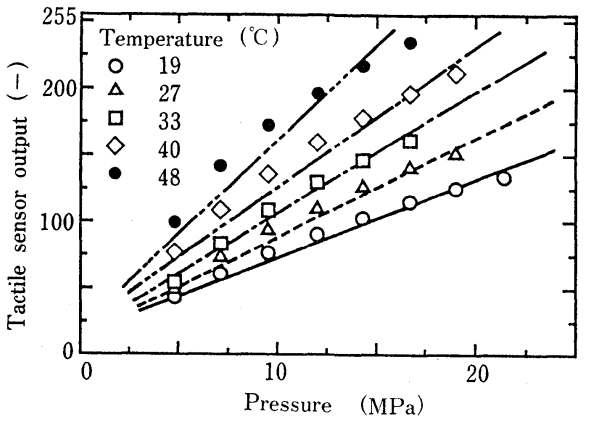

Fig. 6 Influence of the lower plate temperature on the relationship between pressure and tactile sensor output

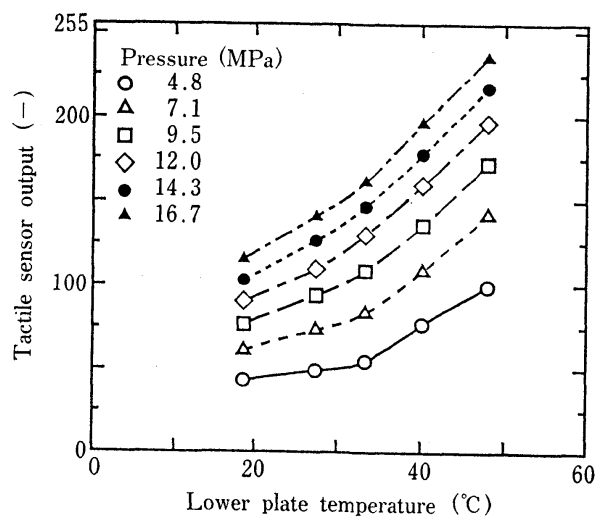

Fig. 7 Relationship between tactile sensor output and lower plate temperature
る. 本センサの最大出力は 255 (無次元量) で, 各プ ロットは 225 点の感圧部出力の平均值を示している. センサ周辺温度 $48^{\circ} \mathrm{C}$ を除いて, 各温度とも圧力とセ ンサ出力の間にはほぼ直線関係が得られている。

Fig. 7 は, Fig. 6 をセンサ周辺温度とセンサ出力の 関係に表記しなおした結果である，温度増加に伴い， センサ出力が増加している．特に $48^{\circ} \mathrm{C} て ゙ は 16.7 \mathrm{MPa}$ でセンサ出力が最大值に達し，測定範囲が小さく制約 された結果となっている。これは，温度上昇によって 導電性物質が軟化し，負荷圧力が同じでも変形量が増 加するためと考えられる。しかし， $35^{\circ} \mathrm{C}$ 以下では単位 温度上昇に対するセンサ出力増加量が比較的小さくな っている.この結果は, センサ周辺温度を低く $\left(35^{\circ} \mathrm{C}\right.$ 以下）制御することにより，広い圧力測定範囲が得ら れることを示唆している.

\section{b . 各感圧部間の出力誤差}

均等圧力負荷条件下に护る 225 点の各感圧部間の 出力誤差（ばらつき）を検討した，本論文では，Fig. 6 中に示されるすべてのプロットの条件に対して, 225 点の出力の標準偏差 $1 \sigma$ をそれぞれ計算し，その中の 最大値を各感圧部間の出力誤差とみなした。計算の結 果，上記誤差は最大士6\% であることが確認された。

\section{c . センサ出力の再現性}

Fig. 8 は，重錘式加圧治具を用いて得られた 50 回 の繰り返し負荷一除荷条件下に护けるセンサ出力の経 時変化を示している. 繰り返し回数の増加に伴ってセ ソサ出力は増加し，30回以降に和いて出力が安定する. これは, 繰り返し動作が引き起こす発熱によって導電 性物質が軟化すること, さらに軟化によって感圧部表 面とピン底部との接触状態がよくなることの 2 点が原 因と考劣られる．30回以降に和けるセンサ出力の再現 性は, $\pm 1.6 \%$ 以内（標準偏差 $1 \sigma$ ）であることを確 認している.

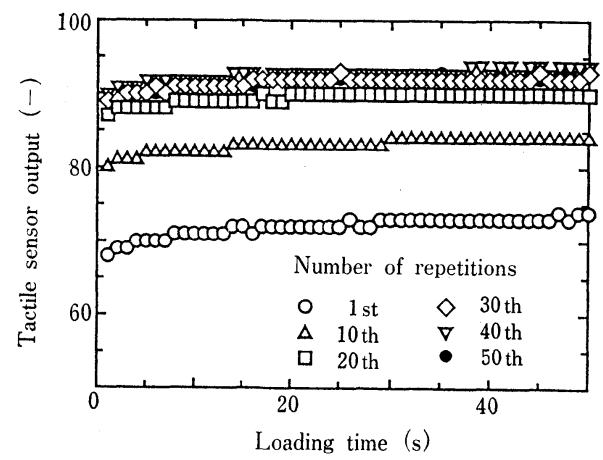

Fig. 8 Influence of the number of repetitions on the relationship between tactile sensor output and loading time 


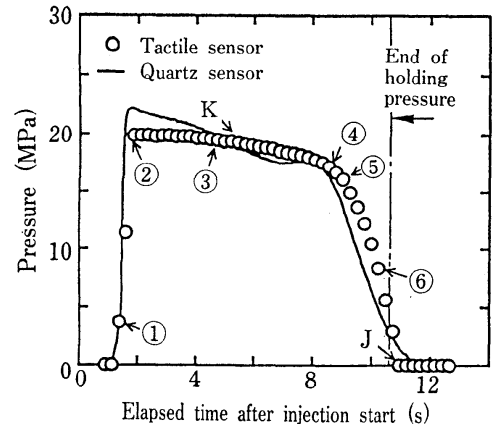

(a) LDPE (Holding pressure period: $9.0 \mathrm{~s}$ )

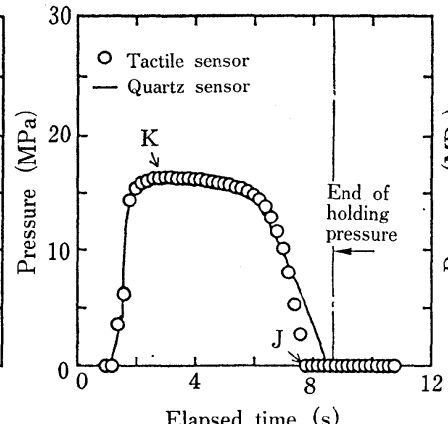

Elapsed time (s)

(b) PP (Holding pressure period: $7.0 \mathrm{~s}$ )

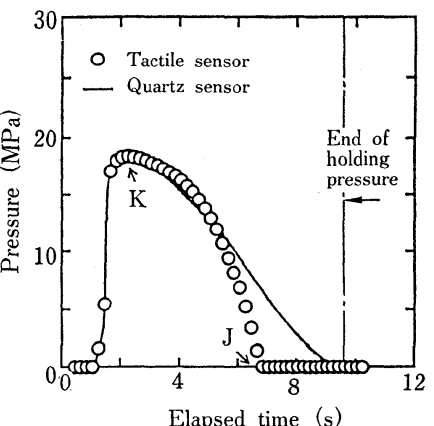

(c) GPPS (Holding pressure

Fig. 9 Comparisons of output in the case of tactile sensor and quartz pressure sensor

\section{2 水晶圧電式圧カセンサによる出力較正}

前節までに本センサの基本特性評価を行ってきた.

しかし, Fig. 6 の較正関係に基づき, 本センサ出力を 圧力に変換することは，以下の理由により困難である もの之判断された。すなおち，(1)金型設定温度を変 化させるたびに較正関係を調査する必要があること， (2) 連続成形時では各ショット毎にセンサ周辺温度が 微妙に変動すること，（3）センサ出力が安定するまで 30 ショットも計測を待たなければならないこと，以 上 3 点が理由としてあげられる.

そこで本論文では, 本センサの出力特性が Fig. 6 亿 示されるようにほぼリニアであることを利用して, 水 晶圧電式圧力センサを用いた実成形中での圧力変換方 法を提案した. 本手法は, 同一位置 (Fig. 4 の C 点) で計測された本センサと水晶圧電式圧力センサ出力を 比較して求めた較正式を, 残りの 224 の計測点に適用 して全体の定量化を行うものである.

Fig. 9 は，LDPE, PP, GPPS をそれぞれ成形して 計測された, Fig. 4 C点での本センサと水晶圧電式圧 カセンサ出力の比較結果を示している. 本センサ圧力 は, 図中の $\mathrm{K}$ 点に和ける水晶圧電式圧力センサ出力を 基準として, 以下の較正式（1）を用いて变換したも のである.

$$
P(t)=\frac{P_{\mathrm{K}}}{T_{\mathrm{K}}} \cdot T(t)
$$

ここで， $P_{\mathrm{K}}$ は水晶圧電式圧力センサの $\mathrm{K}$ 点に扮ける 出力, $T(t)$ は本センサの出力, $T_{\mathrm{K}}$ は本センサの $\mathrm{K}$ 点に打ける出力, $t$ は射出開始後の経過時間を关れぞ れ示す.

Fig. 9 より LDPE に和いて若干の応答遅れが見ら れるものの, 較正された本センサ圧力が水晶圧電式圧 カセンサ出力とよく一致していることがわかる。すな わち, 水晶圧電式圧力センサ出力によって, 本センサ 出力の圧力変換が可能であることを物語る結果となっ ている.
LDPE では, 圧力が 0 亿戻る時点 $\mathrm{J}$ が水晶圧電式 圧力七ンサのそれとほぼ一致している。しかし，PP， GPPSでは, 水晶圧電式圧力センサよりも速く0 亿戻 る傾向を示している．この傾向は特に GPPS におい て顕著に見られ，樹脂の固化層成長速度に起因するる のと推察される。すなわち，GPPSのように成形過程 後半に扮いて硬くて厚い固化層を形成する樹脂に対し ては, 圧力伝達ピン直径 $d_{\mathrm{A}}$ が $1 \mathrm{~mm}$ と小さいため に，固化層が障害となってピン全面に均等圧が加わり にくくなることが原因と考光られる，これは，圧力伝 達ピン方式を用いている本手法の問題点と夕なされ， 樹脂の種類によっては $\mathrm{J}$ 点付近の結果の取り扱いに注 意を要することを示唆している.

\section{3 キャビティ面圧分布計測}

水晶圧電式圧力センサによる压力変換方法の有効性 が実証されたので, 以後, 本センサ出力の較正は上記 方法を用いて行うこととする.

Fig. 10 はキャビティ面圧分布の 経時変化の一例を 示している. ここでは, 全成形過程を通して最もよい 較正結果が得られた Fig. 9 (a) の LDPE の計測結 果を揭げている.

(1)の流動過程ではゲートからフローフロントにかけ て下りのスロープ状圧力分布を示している. (2)，(3)の 圧縮・保圧過程ではキャビティ末端部に比べてゲート 付近の圧力が若干高くなって㜿り, 保圧による補償流 動の効果を表している.

ゲートシールが完了する(4)では, 冷却収縮による圧 力降下がすでに進行している末端部に比べて, ゲート 付近が依然として高い圧力值を維持している．その結 果, ゲート付近から末端部にかけて極端な圧力勾配が 生じている. ゲート付近が高い压力值を維持するのは, 補償流動による残留圧力に起因するものと考兄られる.

(5)，(6では保圧の効果がキャビティ内に全く及ばな くなり，冷却収縮によりキャビティ周辺部を残すよう にして末端部から先に圧力が 0 に戻って行く。 

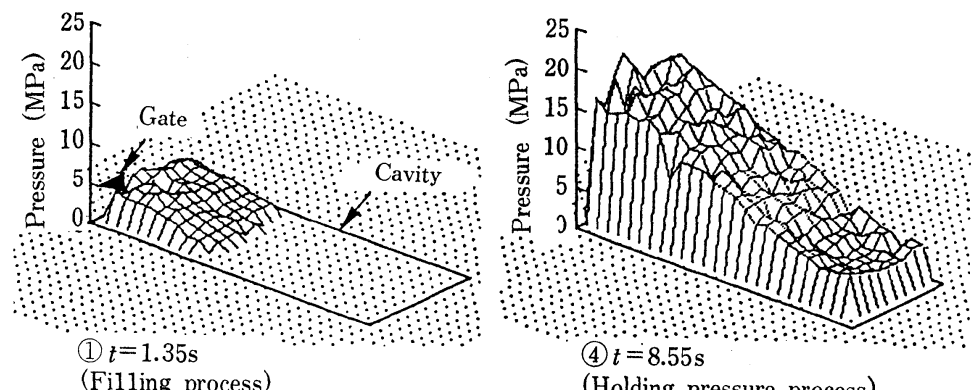

(Filling process)

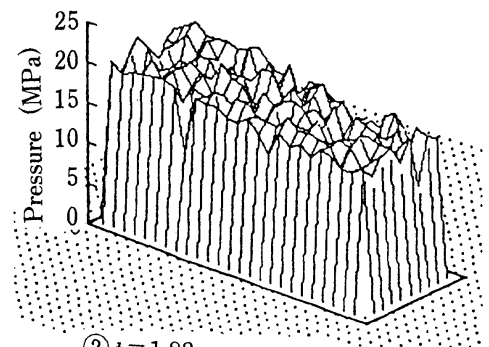

(4) $t=8.55 \mathrm{~s}$

(Holding pressure process)

(2) $t=1.83 \mathrm{~s}$

(Compression process)

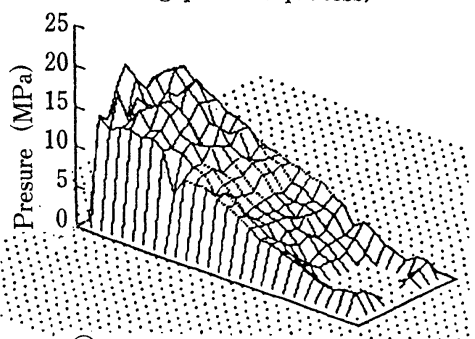

(5) $t=9.03 \mathrm{~s}$

(Holding pressure process)
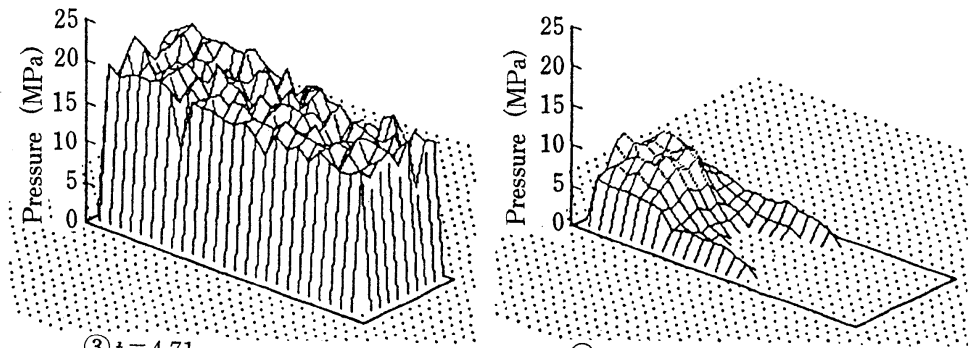

(3) $t=4.71 \mathrm{~s}$

(Holding pressure process)

(6) $t=10.23 \mathrm{~s}$

(Holding prsssure process)

Fig. 10 Melt pressure distribution profiles inside a mold cavity in the case of $9.0 \mathrm{~s}$

holding pressure period (Resin : LDPE, $t$ : Elapsed time after injection start)

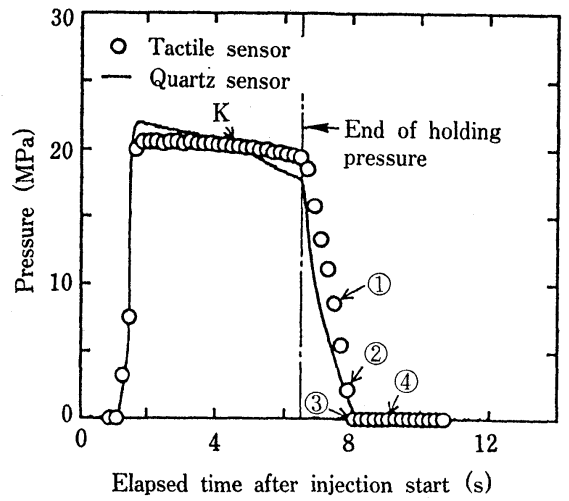

Fig. 11 Pressure curve in the case of $5.0 \mathrm{~s}$ holding pressure period (Resin : LDPE)

ここで, キャビティ周辺部の圧力が最後に低下する 原因は，以下のように考察される.キャビティ周辺部 は, 三方をキャビティ壁面に囲まれているため, 中央 部よりも樹脂の冷却が促進される. そのため, 周辺部
の樹脂は，圧縮・保圧過程において高い圧力を受けな がら急速に冷却される. その結果, 結晶化があまり進 まない状態で早い段階で固化が行われる。いっぽら, 中央部では, 周辺部に比べて相対的に緩やかに冷却さ れる結果, ゲートシール後にも結晶化が促進されて, 収縮量が周辺部より大きくなる.こうした収縮率の相 違が中央部で先に圧力が降下する現象をもたらしたも のと推察される.

次に, ゲートシールが完了する前に保圧を終了した 場合に, 面圧分布状態がどのように変化するかを検討 した. Fig. 11 は，保圧時間を短くして計測した Fig. 4 のC点に拈ける面圧の経時変化を示している. 保生終 了と同時に圧力が急激に 低下している.

Fig. 12 は, Fig. 11 に対応する型内樹脂圧力分布の 経時変化を示している. 保圧終了以前の圧力分布は, Fig. 10の分布と同様であるためここでは省略した. ゲ 一トシール完了前に保圧が終了したために, (1), (2)で はキャビティ内からランナー内への樹脂の逆流が起こ り，それまで高かったダート付近の圧力が急激に低下 


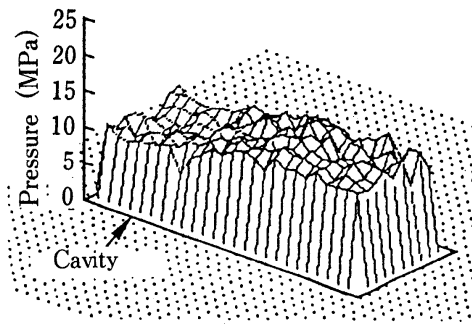

(1) $t=7.47 \mathrm{~s}$

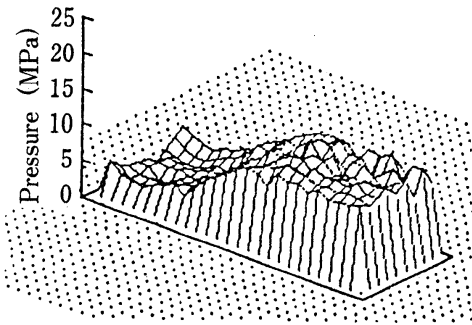

(2) $t=7.87 \mathrm{~s}$

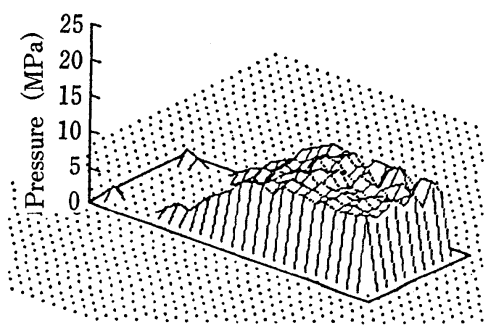

(3) $t=8.07 \mathrm{~s}$

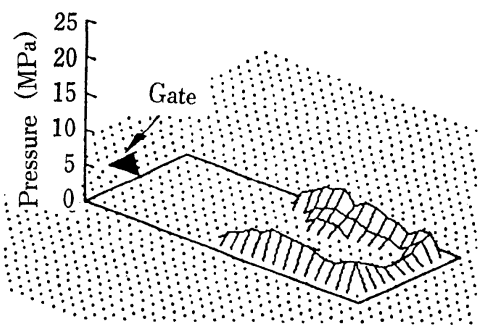

(4) $t=9.07 \mathrm{~s}$

Fig. 12 Melt pressure distribution profiles inside a mold cavity during the cooling process in the case of $5.0 \mathrm{~s}$ holding pressure period (Resin : LDPE, $t$ : Elapsed time after injection start)

を始める、そして，その後(3)，(4)では，ゲート付近か ら先に圧力が 0 に戻るといら Fig. 10 とは全く逆の様相 を呈している.

このように，各感圧部間の $\pm 6 \%$ の出力誤差に起因 する多少の凹凸が分布上に見られるものの，保圧時間 の変化に対応したキャビティ面圧分布変化を詳細に捉 えたこれらの結果は, 本計測法の有効性を充分に実証 しているものと言える。

\section{5. 結言}

以下に，本研究で得られた結論を列記する.

（1）圧力伝達ピンアレイと触覚センサから構成さ れる新しいキャビティ面圧分布計測法を提案した。

（2）触覚センサ出力特性の評価実験を行い, 各感 圧部間の出力誤差（ばらつき）が最大 $\pm 6 \%$ （標 準偏差10)であること，また，本センサの圧力測 定範囲を広げるためには，センサ周辺温度を $35^{\circ} \mathrm{C}$ 以下に制御する必要があることを確認した。

（3）水晶圧電式圧力センサを用いた実成形中に括 ける触覚センサ出力の圧力変換方法を提案し, そ の有効性を確認した。

（4）LDPE に执いて保圧時間を変化させてキャ ビティ面生分布計測実験を行い，ゲートシール時 間よりも保圧時間が長い場合にはキャビティ末端 部から圧力降下が始まる過程を, 逆に保圧時間が
短い場合には，樹脂の逆流によりゲート付近から 圧力降下が始まる過程を，面圧分布経時变化とし て実証的に明らかにした。

本計測手法は, 成形プロセス・不良現象の解明, 拉 よび数值シミュレーション結果の検証に対して有効な 手段となるものと考光られる. 各感圧部間の出力誤差 補正方法を検討し, 測定精度をさらに向上させること により，本計測手法の利用範用が今後ますます広がる ものと期待される。

\section{謝辞}

おわりに，触覚センサに関する技術協力，ならびに 計測金型の製作に協力を賜ったニッタ，住友重機械工 業に謝意を表します。なお，本研究の一部は，東京大 学生産技術研究所の平成 5 年度民間等之の共同研究一 V'93 プロジェクトーにより遂行されたことを記し， 謝意を表します。

\section{参考 文 献}

1）林 博己：プラスチックス, 31（9), 99 (1980)

2）林 雅和：プラスチック成形技術，10（6)，36 (1993)

3）青地保光, 奥山和彦: 成形加工， 1，415（1989）

4) 西脇信彦, 今野政昭, 崔 愛玲, 堀 三計 : 成形 加工, 5, 779 (1993)

5）横井秀俊, 高橋重晶, 村田泰彦：成形加工' 94,181 (1994) 